\title{
Evaluation of Three Helicobacter pylori Eradication Protocols in a Digestive Endoscopy Center in Dakar
}

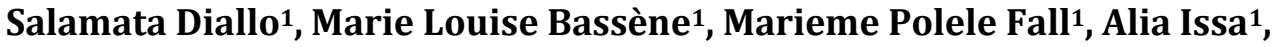 \\ Mame Aisse Thioubou' ${ }^{2}$ \\ ${ }^{1}$ Department of Gastroenterology and Hepatology, Hospital Aristide Le Dantec, Dakar, Senegal \\ ${ }^{2}$ Department of Gastroenterology and Hepatology, Hospital de la Paix, Ziguinchor, Senegal \\ Email: oldou@hotmail.fr
}

How to cite this paper: Diallo, S., Bassène, M.L., Fall, M.P., Issa, A. and Thioubou, M.A. (2021) Evaluation of Three Helicobacter pylori Eradication Protocols in a Digestive Endoscopy Center in Dakar. Open Journal of Gastroenterology, 11, 244-254. https://doi.org/10.4236/ojgas.2021.1111025

Received: August 23, 2021

Accepted: November 19, 2021

Published: November 22, 2021

Copyright (c) 2021 by author(s) and Scientific Research Publishing Inc. This work is licensed under the Creative Commons Attribution International License (CC BY 4.0). http://creativecommons.org/licenses/by/4.0/

\section{Open Access}

\begin{abstract}
Introduction: The treatment of Helicobacter pylori $(H$. pylori) requires the combination of antibiotic therapy with an antisecretory agent. Due to increasing antibiotic resistance, which varies from one geographical region to another, several eradication protocols exist. Objective: The objective is evaluate and compare the efficacy of three treatment regimens for $H$. pylori infection: 1) Arm A: Omeprazole + Amoxicillin + Clarithromycin for 10 days; 2) Arm B: Omeprazole + Amoxicillin + Metronidazole for 10 days; 3) Arm C: Sequential treatment $=$ Omeprazole + Amoxicillin for 5 days then Omeprazole + Clarithromycin + Metronidazole for 5 days. Patients and Method: This was a prospective randomised study conducted from February 2016 to July 2016 and from April 2017 to September 2017 in the digestive endoscopy center of the gastroenterology and hepatology department of the University Hospital Center Aristide Le Dantec. Our study population consisted of all patients aged 18 years or older referred for upper GI endoscopy. We included all patients whose indication for the examination was epigastralgia and/or dyspepsia and whose rapid urease test was positive. Patients were randomized to the different treatment arms. A 13C-urea breath test was performed at least 4 weeks after stopping antibiotics and 2 weeks after stopping proton pump inhibitor (PPI). Results: We included 120 patients. There were 95 women and 25 men. The mean age was 40 years. Epigastralgia and dyspepsia were present in $90 \%$ and $59 \%$ of cases, respectively. Upper GI endoscopy showed peptic ulcer in $19.2 \%$ and gastroduodenal erosions in $42.5 \%$. The distribution of patients in the different treatment arms was as follows: 40 patients in arm A, 39 patients in arm B and 41 patients in arm C. Treatment was effective in $71.7 \%$ of cases in all arms mixed up. Arms A, B and C were effective in 92.5\%, 28.2\%
\end{abstract}


and $92.7 \%$ of cases respectively. The efficacy of arms A and C was like and greater than that of arm B. Conclusion: The therapeutic strategy for $H$. pylori must consider the local microbiological and ecological environment. Clarithromycin triple therapy and sequential treatment represent effective protocols in our patients.

\section{Keywords}

Helicobacter pylori, Epigastralgia, Dyspepsia, Antibiotics, Resistances

\section{Introduction}

Helicobacter pylori (H. pylori) is a ubiquitous Gram-negative bacterium [1] that can colonize the gastric mucosa and be responsible for several pathologies such as chronic gastritis, peptic ulcers, gastric adenocarcinoma, and MALT lymphoma [2].

Chronic infection affects $50 \%$ of the world population [3]. It is more common in developing countries where the prevalence can reach $70 \%$ - 90\%, particularly in Africa and especially in Senegal [4]. Several methods including serology, urea breath test, rapid urease test, faecal antigen test, culture from biopsy, and histological evaluation have good accuracy in the diagnosis of $H$. pylori infection. Eradication of $H$. pylori infection substantially reduces the recurrence of associated gastroduodenal diseases. Treatment requires the combination of antibiotic therapy with aproton pump inhibitor. Its effectiveness depends on the sensitivity of the germ to the different molecules. Several protocols exist due to the appearance of increasing resistance to antibiotics.

A previous study in Dakar evaluated the histological and bacteriological aspects of $H$. pylori infection in patients with gastroduodenal lesions. It determined the in vitro susceptibility of $H$. pylori to metronidazole, ciprofloxacin, clarithromycin, and amoxicillin. This sensitivity was low for metronidazole and high for the other three [5]. In terms of antibiotic resistance, it is necessary to establish a correlation between in vitro and in vivo resistance. Indeed, an antibiotic can be resistant in vitro and effective in vivo and vice versa [6]. It is recognised that the impact of clinical resistance to metronidazole on the eradication rate is less [7] [8].

Therefore, it appeared important to evaluate the effectiveness of the different therapeutic protocols suggested by the different scientific meetings in our population. It is in this context that our study was designed to evaluate and compare the efficacy of three first-line treatment regimens for H. pylori infection:

- Arm A (AOC): Omeprazole + Amoxicillin + Clarithromycin for 10 days.

- Arm B (AOM): Omeprazole + Amoxicillin + Metronidazole for 10 days.

- Arm C (Sequential treatment): Omeprazole + Amoxicillin for 5 days then Omeprazole + Clarithromycin + Metronidazole for 5 days. 


\section{Patients and Method}

This study was performed at the digestive endoscopy unit of the gastroenterology and hepatology department of the University Hospital Center Aristide Le Dantec, in Dakar (Senegal). This was a prospective, randomized, comparative study of 3 combinations of triple therapy for $H$. pylori eradication. The study was conducted over a 12-month period (February 2016 to July 2016 and April 2017 to September 2017).

The study population consisted of patients received for an upper GI endoscopy during the study period. Patients aged 18 years or older, referred for epigastralgia or dyspepsia, with peptic ulcer and/or equivalent or normal endoscopy, with a positive rapid urease test were included, after consent was obtained.

Non-inclusion criteria were:

- The presence at endoscopy of another type of lesion that could be related to H. pylori (a tumor in particular).

- Antibiotics taken in the 30 days preceding the endoscopic examination and antisecretory drugs taken in the 2 weeks preceding the examination.

- Absence of consent.

All patients who did not take the full course of treatment and/or did not complete the $H$. pylori eradication breath test were excluded from the study.

Arm membership was defined according to a randomization grid developed for this purpose.

Cluster randomisation of 15 individuals was performed. Five randomised lists (clusters) of 15 choices were drawn up. Each list contained an equal number of patients from each arm, i.e., 5 patients from each arm, with different randomly generated scenarios. The randomiser selected one of the lists by simple random draw. Then, the membership of the included patients was determined by the scenario (established order) of the selected cluster, until its complete filling, i.e., 15 patients. Once the 15-patient cluster had been completed, another list was drawn, and the procedure was repeated until the target population was reached.

The distribution of patients in the different treatment arms was as follows: 40 patients in arm A, 39 in arm B and 41 in arm C.

For each patient, during the upper GI endoscopy, one biopsy was taken from the antrum for the rapid urease test and 5 others were taken according to the Sydney protocol ( 2 from the antrum, 1 from the angulus, and 2 from the fundus, on the lesser and greater curvature) for the anatomopathological study.

During the ten days, the capsules of Omeprazole, Amoxicillin, clarithromycin and metronidazole were taken twice daily (morning and evening). A 13C-urea breath test was performed at least 4 weeks after stopping antibiotics and 2 weeks after stopping proton pump inhibitor (PPI). Treatment efficacy was characterized by the negativity of the 13C-urea breath test (RT).

A survey form has been performed for each patient. We collected marital status, family and personal history, clinical aspects, results of upper GI endo- 
scopy, histology results of biopsies (classified according to OLGA and OLGIM classifications), treatment regimen, Carbon-13 urea breath test results.

The data were entered and analysed with Microsoft office Excel and R2.2.9 software.

\section{Results}

We included 120 patients. Their mean age was 40 years [extremes $=18$ years -66 years]. Figure 1 shows the age distribution. There were 95 women (79\%), a sex ratio of 0.26 .

Epigastralgia and dyspepsia were present in $90 \%$ and $59 \%$ of cases, respectively (Figure 2).

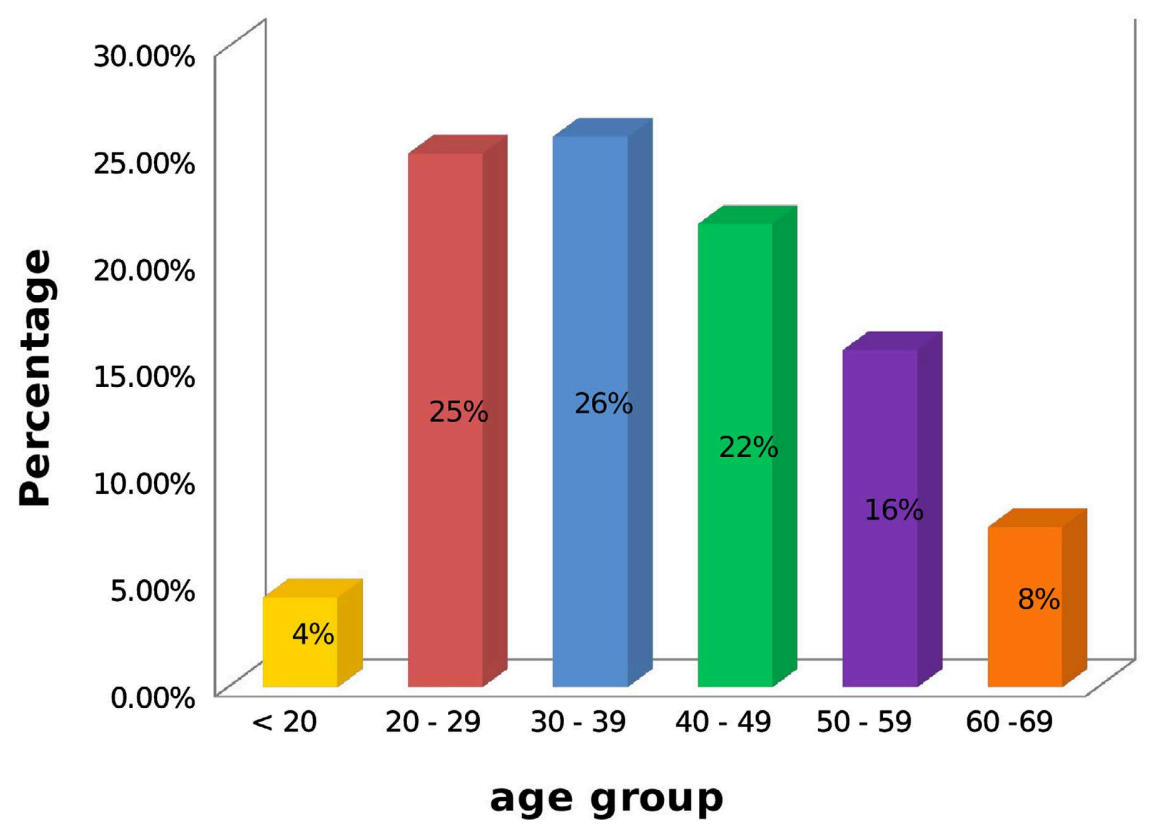

Figure 1. Distribution of patients by age group.

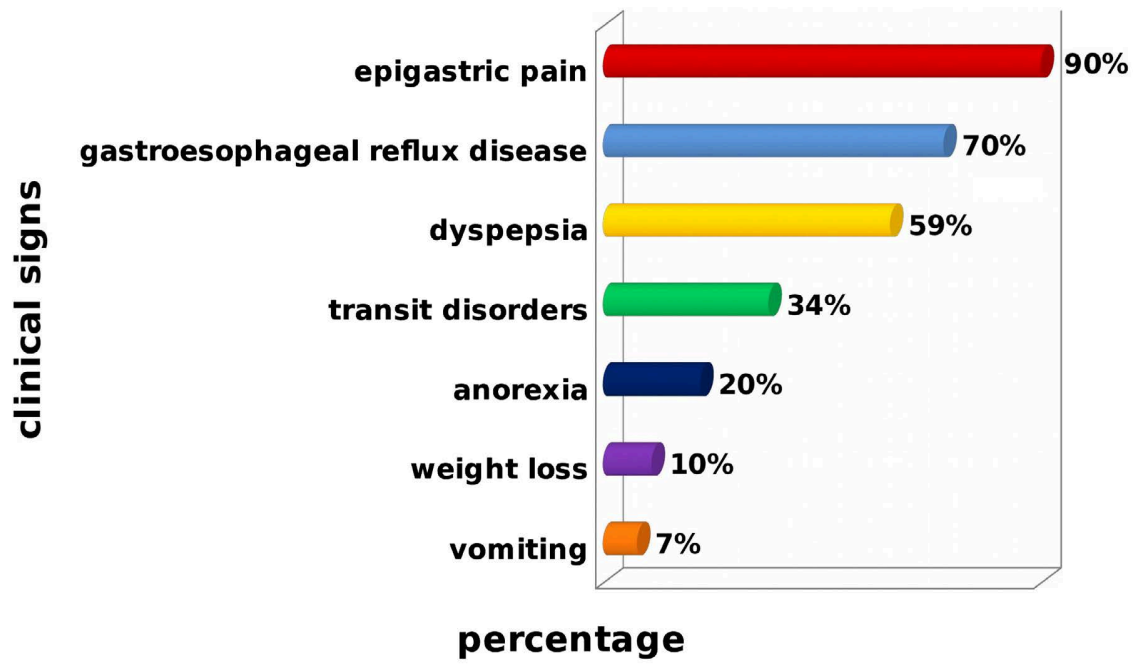

Figure 2. Distribution of patients by clinical signs. 
Upper GI endoscopy showed peptic ulcer in 23 patients (19.2\% of cases) and gastroduodenal erosions in 51 patients (42.5\% of cases). It was normal in 13 patients (10.8\%).

Pathological examination of the biopsies showed $H$. pylori in $73.8 \%$ of cases. Bacterial density was moderate in $25.2 \%$ of cases (Figure 3 ).

Treatment was effective in $71.7 \%$ of cases in all arms mixed up. Arm A was effective in $92.5 \%$ of cases, arm B in $28.2 \%$ of cases and arm C in $92.7 \%$ of cases.

Patients in arm A and arm C were 31.4 times and 32.2 times more likely to have a negative RT than patients in arm B, respectively (Table 1).

Patients in arm A and arm $\mathrm{C}$ had the same chance of having a negative breath test (Table 2).

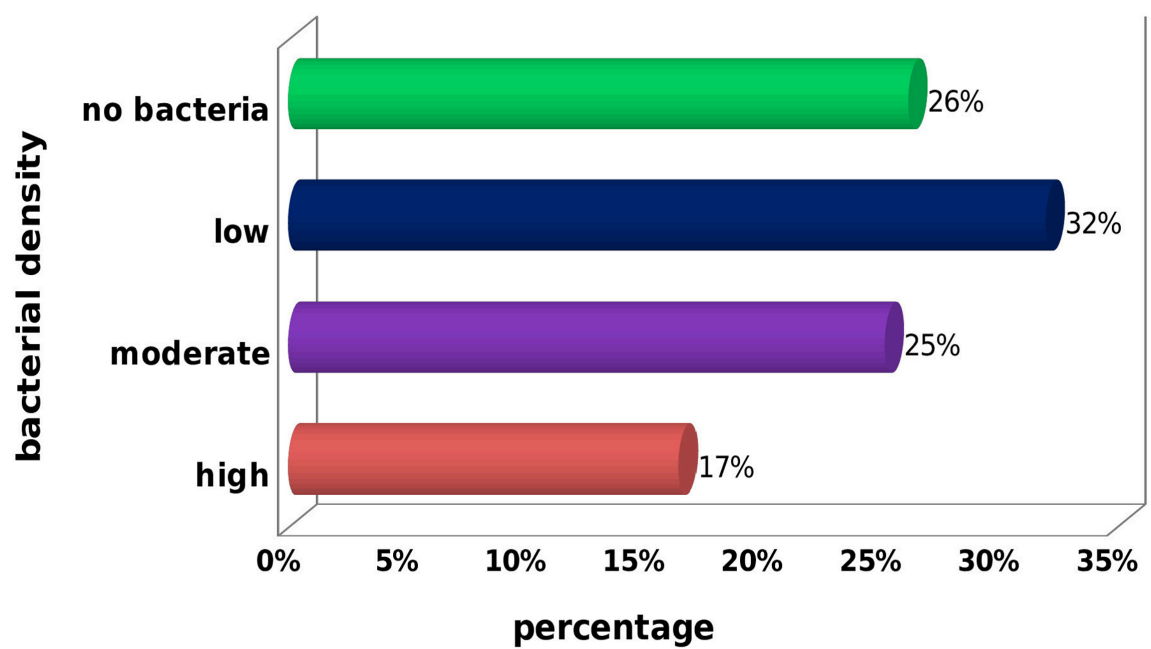

Figure 3. Distribution of patients according to $H$. pylori bacterial density.

Table 1. Comparison of Urea Breath Test results in arm B with those of arms A and C.

\begin{tabular}{cccccccc}
\hline & \multicolumn{7}{c}{ Urea Breath Test } \\
\cline { 2 - 7 } & \multicolumn{7}{c}{ Negative Positive } \\
\cline { 2 - 8 } & N & $\%$ & N & $\%$ & ALL & P value & Ods [95\%] \\
\hline Arm $A$ & 37 & 92.5 & 3 & 7.5 & 40 & 0.0001 & $31.4[8.0-123]$ \\
Arm $C$ & 38 & 92.7 & 3 & 7.3 & 41 & 0.0001 & $32.2[8.2-126]$ \\
Arm $B$ & 11 & 28.2 & 28 & 71.8 & 39 & Ref & 1 \\
\hline
\end{tabular}

Table 2. Comparison of Urea Breath Test results in Arm A with those in Arm C.

\begin{tabular}{|c|c|c|c|c|c|c|c|}
\hline & \multicolumn{7}{|c|}{ Urea Breath Test } \\
\hline & \multicolumn{7}{|c|}{ Negative Positive } \\
\hline & $\mathbf{N}$ & $\%$ & $\mathbf{N}$ & $\%$ & All & $P$ value & Ods [95\%] \\
\hline $\operatorname{Arm} A$ & 37 & 92.5 & 3 & 7.5 & 40 & Ref & \\
\hline $\operatorname{Arm} C$ & 38 & 92.7 & 3 & 7.3 & 41 & 0.999 & \\
\hline
\end{tabular}


Treatment efficacy was the same regardless of age group ( $<40$ years vs $\geq 40$ years) and gender (Table 3). Patients with epigastralgia had eradication rates of 91.7\%, 33.3\% and $92.3 \%$ in arms A, B and C, respectively. In dyspeptic patients, the eradication rates in arms $\mathrm{A}, \mathrm{B}$, and $\mathrm{C}$ were $96.1 \%, 17.4 \%$, and $95.4 \%$, respectively (Table 3 ). In cases of normal upper GI endoscopy, treatment was effective in all patients in arms $\mathrm{A}$ and $\mathrm{C}$ and in $28.6 \%$ of cases in arm B.

The eradication rate was $85.7 \%, 12.5 \%$, and $87.5 \%$ in arms $\mathrm{A}, \mathrm{B}$, and $\mathrm{C}$, respectively, in patients with peptic ulcer. It was $94.4 \%, 20.8 \%$, and $96.3 \%$ in arms A, B, and C, respectively, in patients with gastroduodenal erosions (Table 4).

\section{Discussion}

In our study, arm A (AOC) was effective in $92.5 \%$ of cases, arm B (AOM) in $28.2 \%$ of cases and arm C (sequential treatment) in $92.7 \%$ of cases.

The eradication thresholds recommended by the Maastricht V/Florence consensus conference being $80 \%$ [8] and we can say that AOC and sequential treatment are associated with better chances of Hp eradication. AOM triple therapy seems to be ineffective.

Triple AOC therapy is as effective as sequential therapy in our patients.

Our results are different from those reported in studies performed in North

Table 3. Distribution of patients by Urea Breath Test and age, gender, clinical signs.

\begin{tabular}{|c|c|c|c|c|c|c|c|c|c|c|c|c|c|}
\hline \multirow{3}{*}{\multicolumn{2}{|c|}{ Characteristics }} & \multicolumn{12}{|c|}{ Urea Breath Test } \\
\hline & & \multicolumn{3}{|c|}{ All } & \multicolumn{3}{|c|}{$\operatorname{Arm} \mathrm{A}$} & \multicolumn{3}{|c|}{ Arm B } & \multicolumn{3}{|c|}{ Arm C } \\
\hline & & $\begin{array}{c}\text { Negative } \\
\text { N (\%) }\end{array}$ & $\begin{array}{c}\text { Positive } \\
\text { N (\%) }\end{array}$ & $P$ value & $\begin{array}{c}\text { Negative } \\
\text { N (\%) }\end{array}$ & $\begin{array}{c}\text { Positive } \\
\text { N (\%) }\end{array}$ & $P$ value & $\begin{array}{c}\text { Negative } \\
\mathrm{N}(\%)\end{array}$ & $\begin{array}{c}\text { Positive } \\
\text { N (\%) }\end{array}$ & P value & $\begin{array}{c}\text { Negative } \\
\text { N (\%) }\end{array}$ & $\begin{array}{c}\text { Positive } \\
\text { N (\%) }\end{array}$ & $P$ value \\
\hline \multirow[b]{2}{*}{ Age group } & $\begin{array}{c}<40 \\
\text { years }\end{array}$ & $\begin{array}{c}19 \\
(90.5)\end{array}$ & $2(9.5)$ & \multirow[b]{2}{*}{0.609} & $6(30)$ & $14(70)$ & \multirow[b]{2}{*}{0.798} & $19(95)$ & $1(5)$ & \multirow[b]{2}{*}{0.578} & $44(72.1)$ & $17(27.9)$ & \multirow[b]{2}{*}{0.908} \\
\hline & $\begin{array}{c}\geq 40 \\
\text { years }\end{array}$ & $18(94.7)$ & $1(5.3)$ & & $5(26.3)$ & $14(73.7)$ & & $19(90.5)$ & $2(9.5)$ & & $42(71.2)$ & $17(28.8)$ & \\
\hline Gender & $\begin{array}{c}\text { Female } \\
\text { Male }\end{array}$ & $\begin{array}{l}31(93.9) \\
6(85.7)\end{array}$ & $\begin{array}{l}2(6.1) \\
1(14.3)\end{array}$ & 0.453 & $\begin{array}{c}7(28) \\
4(28.6)\end{array}$ & $\begin{array}{c}18(72) \\
10(71.4)\end{array}$ & 0.969 & $\begin{array}{c}20(95.2) \\
18(90)\end{array}$ & $\begin{array}{l}1(4.8) \\
2(10)\end{array}$ & 0.519 & $\begin{array}{l}58(73.4) \\
28(68.3)\end{array}$ & $\begin{array}{l}21(26.6) \\
13(37.7)\end{array}$ & 0.554 \\
\hline $\begin{array}{c}\text { Epigastric } \\
\text { pain }\end{array}$ & $\begin{array}{l}\text { Yes } \\
\text { No }\end{array}$ & $\begin{array}{c}33(91.7) \\
4(100)\end{array}$ & $\begin{array}{c}3(8.3) \\
0(0)\end{array}$ & 0.548 & $\begin{array}{c}11(33.3) \\
0(0)\end{array}$ & $\begin{array}{c}22(66.7) \\
6(100)\end{array}$ & 0.095 & $\begin{array}{c}36(92.3) \\
2(100)\end{array}$ & $\begin{array}{c}3(7.7) \\
0(0)\end{array}$ & 0.683 & $\begin{array}{c}80(74.1) \\
6(50)\end{array}$ & $\begin{array}{c}28(25.9) \\
6(50)\end{array}$ & 0.079 \\
\hline Dyspepsia & $\begin{array}{l}\text { Yes } \\
\text { No }\end{array}$ & $\begin{array}{l}25(96.1) \\
12(85.7)\end{array}$ & $\begin{array}{c}1(3.9) \\
2(14.3)\end{array}$ & 0.231 & $\begin{array}{l}4(17.4) \\
7(43.7)\end{array}$ & $\begin{array}{l}19(82.6) \\
9(56.3)\end{array}$ & 0.072 & $\begin{array}{l}21(95.4) \\
17(89.5)\end{array}$ & $\begin{array}{c}1(4.5) \\
2(10.5)\end{array}$ & 0.463 & $\begin{array}{l}50(70.4) \\
36(73.5)\end{array}$ & $\begin{array}{l}21(29.6) \\
13(26.5)\end{array}$ & 0.715 \\
\hline
\end{tabular}

Table 4. Eradication rates by upper GI endoscopy results and treatment arms.

\begin{tabular}{cccc}
\hline & Arm A & Arm B & Arm C \\
\hline No lesion & $100 \%$ & $28.6 \%$ & $100 \%$ \\
Gastroduodenal erosion & $94.4 \%$ & $20.8 \%$ & $96.3 \%$ \\
Peptic ulcer & $85.7 \%$ & $12.5 \%$ & $87.5 \%$ \\
\hline
\end{tabular}


Africa, Europe, Asia and the Middle East where the eradication rate is higher with sequential treatment than with triple therapy [8] [9] [10] [11] [12]. This is probably due to the difference in sensitivity to clarithromycin of $H$. pylori strains. In Senegal, Hp resistance to clarithromycin is low [13], whereas it varies from $20 \%$ to $40 \%$ in these regions] [8].

In our study, arm A (AOC) was effective in $92.5 \%$ of cases. In Senegal, a study evaluated the efficacy of AOC triple therapy over 7 days [14]. It found an eradication rate of $79.3 \%$ per protocol. Longer treatment duration improves results. Indeed, a Tunisian study showed that eradication rates with 10-day triple therapy were higher than with 7-day therapy. Extending the treatment to 14 days did not show superiority [8] [15].

An eradication rate of $21.4 \%$ was found in an Ivorian study [16]. In North Africa, Europe and the Middle East, the efficacy of AOC treatment was also below the threshold set by the learned societies (80\%). It varied between $58 \%$ and $73 \%$ [10] [15] [17]. This ineffectiveness is related to the high resistance of $H$. pylori to clarithromycin in these regions. In Côte d'Ivoire it was $26.5 \%$ and elsewhere it ranged from $20 \%$ to $40 \%$ [8] [16] [18]. The development of resistance depends on many parameters, notably geographical, ethnic and the prescription habits of local practitioners [19]. To date, in Senegal, the sensitivity of $H$. pylori strains to clarithromycin is $96.6 \%$ [5].

The very low eradication rate obtained with triple AOM therapy $(28.2 \%)$ is also reported in the literature [8] [10] [16]. The sometimes-abusive use of metronidazole in our regions, linked to the frequency of parasitic diseases, could explain the resistance of $\mathrm{Hp}$ to this molecule and the inefficiency of this triple therapy.

Sequential treatment was effective in $92.7 \%$ of cases. Several studies have shown its effectiveness with eradication rates ranging from $86.7 \%$ to $98.1 \%$ [20] [21]. The use of amoxicillin in the first phase of treatment would reduce the impact of resistance to clarithromycin [22]. Indeed, amoxicillin decreases the bacterial load and weakens the wall of $H$. pylori. This leads to an increase in the intra-bacterial concentration of clarithromycin and improves its bacteriostatic activity [22] [23].

However, the Maastricht V/Florence consensus conference found in its meta-analysis an overall efficacy rate of $75 \%$, which is lower than the efficacy threshold set at $80 \%$ [24]. The frequent association in some industrialized countries of a double resistance clarithromycin-metronidazole could explain this result. Also, the sequential treatment protocol is often misunderstood by patients, thus compromising compliance [8].

In our study, the mean age of the patients was 40 years and $51 \%$ were under 40 years. This young age was also found in other studies in Senegal [4] [5] [13] [14] and elsewhere in Africa [15] [25] [26]. In Europe, Asia and the Middle East, patients were often older at diagnosis [27] [28] [29]. The rise in socio-economic status in industrialised countries may account for the lower infection rate in younger subjects, with a cohort effect possibly explaining this difference in age at 
diagnosis. In our study, age had no impact on the effectiveness of the different treatments. Indeed, whatever the average age and the age group, the effectiveness of the treatment was the same.

In our study, the female gender was predominant with $79 \%$ of women (sex ratio of 0.26). These results are in contradiction with those obtained in other Senegalese, Moroccan and Algerian studies where the predominance was male [4] [5] [14] [15] [30]. However, in Asia, studies from Korea and China have shown a current trend towards female predominance with rates of $53.2 \%$ and $52.1 \%$ respectively [18] [31]. In our patients, regardless of gender and arm, treatment efficacy was the same. About the eradication of $H$. pylori, female gender is thought to be a factor affecting the efficacy of treatment [18] [31]. Indeed, physiological, hormonal, immune and inflammatory differences could directly or indirectly interfere with the response to treatment. The parameters most frequently implicated are the presence of higher levels of interleukin-35 and the frequency of the A2143G point mutation (a point mutation predisposing to resistance to clarithromycin) in $H$. pylori strains infecting women [18].

In our study, $90 \%$ of patients had epigastralgia and $59 \%$ had dyspepsia. Our results corroborate those found in previous studies in Senegal where the indications for EOGD were dominated by these two clinical signs [4] [32]. Their presence had no impact on the efficacy of treatment. In this study, age, gender and clinical signs didn't influence the effectiveness of eradicative treatment.

The study limitation was the small sample size that did not allow proper interpretation of the P-value.

\section{Conclusion}

Our study shows that clarithromycin triple therapy and sequential treatment are effective regimens for $\mathrm{Hp}$ eradication while eradication rates of metronidazole triple therapy are low. National multicenter studies are needed to evaluate the efficacy of Hp eradication protocols in the Senegalese population and to establish recommendations considering the local epidemiological, economic and ecological context.

\section{Conflicts of Interest}

The authors declare no conflicts of interest regarding the publication of this paper.

\section{References}

[1] De Korwin, J.D. and Bretagne, J.F. (2003) Avantages et inconvénients des différentes méthodes diagnostiques de l'infection a Helicobacter pylori. EMC Gastroentérologie Clinique et Biologique, 27, 380-390.

[2] De Korwin, J.D. and Lehours, P. (2010) Helicobacter pylori: Notions Fondamentales, épidémiologie, méthodes diagnostiques. EMC Gastroentérologie Clinique et Biologique, 9, 1-16. https://doi.org/10.1016/S1155-1968(10)50083-X

[3] Hassan, M.N., Arif, A., Shahzad, M.S., et al. (2020) Global Prevalence of Helicobacter 
pylori and Its Effects on Human Health. $P A B, 9,936-948$.

https://doi.org/10.19045/bspab.2020.90098

[4] Diouf, M.L., Ondélé Ipongo, A.P., Dia, D., et al. (2011) Évolution de la prévalence des ulcères gastroduodénaux dans le centre d'endoscopie digestive de l'hôpital Aristide Le Dantec de Dakar. JAHG, 5, 23-27. https://doi.org/10.1007/s12157-010-0236-4

[5] Dia, D., Seck, A., Mbengue, M., et al. (2010) Helicobacter pylori et pathologie gastroduodénale a Dakar (Sénégal). Medecine Tropicale, 70, 367-370.

[6] Charles, W. (2006) In Vitro Susceptibility Testing versus in Vivo Effectiveness. Medical Clinics of North America, 90, 1077-1088.

https://doi.org/10.1016/j.mcna.2006.07.003

[7] Courillon-Mallet, A. (2005) Résistance de Helicobacter pylori: Chez qui s'acharner et comment? FMC HGE. Post'U; Arch: 33-40.

https://www.fmcgastro.org/postu-main/archives/postu-2005-paris/resistance-de-hel icobacter-pylori-chez-qui-s'acharner-et-comment

[8] Malfertheiner, P., Megraud, F., O’Morain, C., et al. (2017) Management of Helicobacter pylori Infection-The Maastricht V/Florence Consensus Report. Gut, 66, 6-30.

https://doi.org/10.1136/gutjnl-2016-312288

[9] Malfertheiner, P., Megraud, F., O'Morain, C., et al. (2007) The European Helicobacter Study Group. Current Concepts in the Management of Helicobacter pylori Infection-The Maastricht III Consensus Report. Gut, 56, 772-781.

https://doi.org/10.1136/gut.2006.101634

[10] Abuhammour, A., Dajani, A., Nounou, M., et al. (2016) Standard Triple Therapy versus Sequential Therapy for Eradication of Helicobacter pylori in Treatment Naïve and Retreat Patients. Arab Journal of Gastroenterology, 17, 131-136. https://doi.org/10.1016/j.ajg.2016.07.001

[11] Benajah, D.A., et al. (2012) Le traitement séquentiel est supérieur à la trithérapie standard dans l'éradication d'Helicobacter pylori chez les patients naïs au traitement: Résultats d'une étude prospective randomnisée HPFEZ.FMC HGE. Post'U; Arch (CO.54).

https://www.fmcgastro.org/postu-main/archives/best-of-2012/le-traitement-sequent iel-est-superieur-a-la-tritherapie-standard-dans-l'eradication-d'helicobacter-pylorichez-les-patients-naifs-au-traitement-resultats-d'une-etude-prospect

[12] Fock, K.M., Katelaris, S.K., et al. (2009) Second Asia-Pacific Consensus Guidelines for Helicobacter pylori Infection. Journal of Gastroenterology and Hepatology, 24, 1587-1600. https://doi.org/10.1111/j.1440-1746.2009.05982.x

[13] Seck, A., Burucoa, C., Dia, D., et al. (2013) Primary Antibiotic Resistance and Associated Mechanisms in Helicobacter pylori Isolates from Senegalese Patients. Annals Clinical Microbiology Antimicrobials, 12, 3-6.

https://doi.org/10.1186/1476-0711-12-3

[14] Fall, F., Diagne, A., Ndiaye, B., et al. (2011) Tritherapie par omeprazole, amoxicilline et clarithromycine dans la maladie ulcereuse duodenale associee a Helicobacter pylori au Senegal. JAHG, 5, 28-32. https://doi.org/10.1007/s12157-010-0237-z

[15] Bensaada, R., Bouani, B., Soussi, Y., et al. (2019) Ulcère à Helicobacter pylori: Efficacité du traitement et facteurs influençant la guérison. Le Pharmacien Hospitalier et Clinicien, 54, 342-347. https://doi.org/10.1016/j.phclin.2019.07.007

[16] Doffou, A.S., Attia, K., Bathaix, M., et al. (2015) The Helicobacter pylori Eradication Rate in a High Prevalence Area (West Africa): Three Triple Therapy Comparative Study. Open Journal of Gastroenterology, 5, 200-206. 
https://doi.org/10.4236/ojgas.2015.512030

[17] Delchier, J.C. and Parsonnet, J. (2020) Efficacy of a Tailored PCR-Guided Triple Therapy in the Treatment of Helicobacter pylori Infection. Médecine et Maladies Infectieuses, 50, 492-499. https://doi.org/10.1016/j.medmal.2019.06.001

[18] Chang, Y.W., Ko, W.J., et al. (2019) Clarithromycin Resistance and Female Gender Affect Helicobacter pylori Eradication Failure in Chronic Gastritis. The Korean Journal of Internal Medicine, 34, 1022-1029. https://doi.org/10.3904/kjim.2018.054

[19] Hu, Y., Zhu, H., Lu, N., et al. (2017) Novel and Effective Therapeutic Regimens for Helicobacter pylori in an Era of Increasing Antibiotic Resistance. Frontiers in Cellular and Infection Microbiology, 7, 2-22. https://doi.org/10.3389/fcimb.2017.00168

[20] Paoluzi, O.A., Visconti, E., Andrei, F., et al. (2010) Ten and Eight-Day Sequential Therapy in Comparison to Standard Triple Therapy for Eradicating Helicobacter pylori Infection: A Randomized Controlled Study on Efficacy and Tolerability. Journal of Clinical Gastroenterology, 44, 261-266. https://doi.org/10.1097/MCG.0b013e3181acebef

[21] Zullo, A., Rinaldi, V., Winn, P., et al. (2000) A New Highly Effective Short-Term Therapy Schedule for Helicobacter pylori Eradication. Alimentary Pharmacology \& Therapeutics, 14, 715-718. https://doi.org/10.1046/j.1365-2036.2000.00766.x

[22] Megraud, F., Coenen, S., Versporten, A., et al. (2013) Helicobacter pylori Resistance to Antibiotics in Europe and Its Relationship to Antibiotic Consumption. Gut, 62, 34-42. https://doi.org/10.1136/gutjnl-2012-302254

[23] Adachi, T., Matsui, S., Watanabe, T., et al. (2017) Comparative Study of Clarithromycin versus Metronidazole Based Triple Therapy as First-Line Eradication for Helicobacter pylori. Oncology, 93, 15-19. https://doi.org/10.1159/000481224

[24] Gisbert, J.P., Calvet, X., O’Connor, A., et al. (2010) Sequential Therapy for Helicobacter pylori Eradication: A Critical Review. Journal of Clinical Gastroenterology, 44, 313-325. https://doi.org/10.1097/MCG.0b013e3181c8a1a3

[25] Lawson-Ananissoh, L., Bouglouga, O., Bagny, A., et al. (2015) Profil épidémiologique des ulcères gastro-duodénaux au centre hospitalier et universitaire Campus de Lomé (Togo). Journal Africain d Hépato-Gastroentérologie, 9, 99-103. https://doi.org/10.1007/s12157-015-0597-5

[26] Olusoji, A., Ajayi, A.O., Adegum, P.T., et al. (2015) Effectiveness of Triple Therapy Regimens in the Eradication of Helicobacter pylori in Patients with Uninvestigated Dyspepsia in Ekiti State, Nigeria. BJMM, 6, 278-285. https://doi.org/10.9734/BJMMR/2015/14103

[27] Khalife, H., Ghssein, G., et al. (2017) Epidemiology of Helicobacter pylori Infection among the Healthy Population in Lebanon. World Journal of Pharmaceutical Sciences, 6, 363-372. https://doi.org/10.20959/wjpps20176-9298

[28] Lee, H.J., Kim, J., Lee, J.S., et al. (2015) Concomitant Therapy Achieved the Best Eradication Rate for Helicobacter pylori among Various Treatment Strategies. World Journal of Gastroenterology, 21, 351-359.

[29] Seher, C., Thierfelder, W., Dortschy, R., et al. (2000) Helicobacter pylori: Prävalenz in der deutschen Bevolkerung. Gesundheitswesen, 62, 598-603. https://doi.org/10.1055/s-2000-13047

[30] Lahbabi, M., Alaoui, S., El Rhazi, K., et al. (2013) Sequential Therapy versus Standard Triple-Drug Therapy for Helicobacter pylori Eradication: Result of the HPFEZ Randomised Study. Clinics and Research in Hepatology and Gastroenterology, 37, 416-421. https://doi.org/10.1016/j.clinre.2012.10.002

[31] Hong, W., Tang, H., Dong, X., et al. (2019) Prevalence of Helicobacter pylori Infec- 
tion in a Third-Tier Chinese City: Relationship with Gender, Age, Birth-Year and Survey Years. Microbiota in Health and Disease, 1, 1-12.

[32] Attia, K.A., Fall, F. and Njoya, O. (2019) Guide de Prise en Charge de la dyspepsie fonctionnelle en Afrique. Médecine d Afrique Noire, 1, 1-84. 